\title{
Economic Equality and Victory in War: An Empirical Investigation
}

\author{
James K. Galbraith, Corwin Priest, \& George Purcell
}

The University of Texas Inequality Project

The University of Texas at Austin

Austin, Texas 78712

UTIP Working Paper \#37

June 13, 2006

\begin{abstract}
:
This paper tests a simple hypothesis: that given the occurrence of war between two countries, the country that is more egalitarian at the moment of military decision is likely to emerge the victor. First, we examine cases where comparative economic inequality can be measured directly, using the nearly comprehensive global data-sets of the University of Texas Inequality Project for the years 1963-1999. Second, we examine cases where reasonable inferences about comparative economic inequality may be drawn by analogy to UTIP measurements or from other political and economic evidence, including both bi-national wars and larger wars where there existed clear pair-wise fronts. Third, we discuss selected cases where inferences may be drawn from literary or historical sources. We find, all in all, that the evidence for an egalitarian victory proposition is remarkably strong.
\end{abstract}

Corresponding author: James K. Galbraith, Galbraith@mail.utexas.edu Comments welcome. 


\section{Introduction}

This paper tests a simple hypothesis: that given the occurrence of war between two countries, the country that is more egalitarian at the moment of military decision is likely to emerge the victor.

In pioneering work, Reiter and Stam (2002) argue that political democracies have a "fourth virtue": victory in war. They attribute this primarily to better choices of when to initiate wars, to better military leadership and to better morale and stronger commitment among the fighting men.

Reiter and Stam's concept of democracy emphasizes accountability and the formal process of selecting government by vote. A drawback of their argument is that democracy so defined is in the eye of the beholder; in formal democracies the "consent of the governed" is rarely comprehensive. In particular, slaves were common in self-described democracies until the mid$19^{\text {th }}$ century, and women were denied the right to vote almost everywhere until well into the $20^{\text {th }}$. Yet if one defines such countries as democratic, then how to treat those, like apartheid South Africa, which restricted the franchise on racial grounds? ${ }^{1}$ The classification of states in occupation of other populations, such as modern Israel, is problematic for reasons that differ de jure but hardly in practice.

Even allowing an elastic definition, there haven't been that many wars pitting democratic against non-democratic countries. Reiter and Stam's entire case rests on just 34 examples of democracies at war from 1816 to 1990 , of which only 15 represent cases where the democracy is classed as the initiator.

Nevertheless, the idea that military decision might rest heavily on a single variable is seductive. And if the presence of democracy has some explanatory power, perhaps another variable will have even more. From a research standpoint, the hypothesis of "egalitarian victory" has several significant advantages. Most notably, it can be applied in principle to all wars between welldefined pairs of major combatants. One party is always more equal, and the other less so. In the case of regional or global wars, the comparison may be applied (with less assurance) to welldefined pair-wise fronts. The limitation is not conceptual, but only a matter of measurement.

The egalitarian victory hypothesis also avoids a thorny problem facing the democratic victory alternative, namely that of distinguishing between "initiators" and "targets," a distinction deemed necessary to excuse cases when democracies lost wars that they would probably have avoided if they could have. "Initiators" can be provoked, as the Austro-Hungarian Empire was in 1914 and the Japanese undoubtedly were in 1941. In any event, the history of how wars started is often written differently by the different contestants. The hypothesis of "egalitarian victory" refers to conditions at the moment of military decision, by which time the attribution of blame for the start of the war has often lost relevance. Framed this way, the hypothesis also allows the possibility that economic conditions can evolve during the course of war.

\footnotetext{
1 Acemoglu and Robinson (2006) treat apartheid South Africa as a canonical non-democracy. But it had free and fair elections among white voters, including women. How is a country where women don't vote a democracy, whereas one where people of color don't vote is not?
} 
A priori, why might the more egalitarian belligerent enjoy a military advantage? We can think of three plausible reasons. First, egalitarian countries have stronger social solidarity, and therefore better military morale. Second, inegalitarian countries often structure their armed forces to handle internal regime security, at the expense of efficiency in meeting external threats. Third, deeply unequal countries face a problem of loyalty in the lower ranks. An egalitarian adversary will often be seen as a liberator by at least some substantial part of the home population; if prudent it will take military advantage of that image.

This paper examines three classes of evidence. First, we look at cases where comparative economic inequality can be measured directly, using the wide-ranging global data sets of the University of Texas Inequality Project for the years 1963-1999. Second, we examine cases where reasonable inferences about comparative economic inequality may be drawn by analogy to UTIP measurements or from other political and economic evidence, including both bi-national wars and larger wars where there existed clear pair-wise fronts. Third, we discuss selected cases where inferences may be drawn from literary or historical sources. We find, all in all, that the evidence for an egalitarian victory proposition is remarkably strong.

This conclusion ought to unsettle neoconservative imperialists, if any remain following three years of bitter American experience in Iraq. For it seems that the pursuit of the free market economic policy agenda ${ }^{2}$ may be mortally destructive to the military effectiveness of the forces required to underpin and, in some cases, to implement that agenda. Conversely, populations that band together to resist the encroachment of free markets, global corporations and the mercenaries who advance their causes may enjoy a military advantage, hitherto unnoticed, yet frequently decisive or at least highly predictive of the outcome.

\section{Definitions}

We offer the hypothesis that when two countries fight a war, the more economically equal usually prevails. We need therefore to define three terms: "country," "war," and "economically equal."

To begin with, we restrict our attention to wars between territorial nation-states in the recognizably modern sense of that term. Greek city-states qualify, as would the Aztecs of Mexico and the Incas of Peru. Tribes such as the Cherokee or the Zulu or the Mahdi Army do not qualify, notwithstanding egalitarian social structures and considerable fighting prowess. It is accurate to describe these entities as "nations," but it seems a stretch to qualify them as countries. Civil wars only qualify if carried out between territorial entities claiming country status: the U.S. Civil War qualifies, but the Spanish Civil War would not. ${ }^{3}$

War we define as a sustained conflict between organized forces, usually leading to military decision: win, lose or draw. Skirmishes, coups and national wars of liberation are excluded, except where they were part of a defined bi-national or multi-national conflict, as in the case of

\footnotetext{
2 These policies are generally known outside the United States as "neoliberal" and comprise the wellknown "Washington Consensus" recommendations of the World Bank and International Monetary Fund. 3 The Chinese and Russian civil wars were fought between entities that held well-defined territories for long times; however despite the obvious temptation to count them for our hypothesis we exclude them.
} 
Vietnam. Massacres, riots and revolutions are also not wars. For a list of candidate-wars, we use the well-established Correlates of War data set for conflicts going back to 1815 .

Finally, there is the problem of defining "economic equality." Here we emphasize relative equality in the structure of economic earnings, especially pay, as this represents our best comparative measure of the social structure of a country, closely related to, but not exactly the same as, measures of income inequality by person or household. It is a variable for which we have the most direct and reliable measurements in the modern period, and the best chance of making reasonable inferences with respect to earlier times. We shall discuss the inequality measures in detail in the next section.

\section{Inequality Measures and Methods}

The University of Texas Inequality project has developed a nearly comprehensive worldwide data set of annual measures of pay inequality for the years 1963 to 1999 , with nearly 3,200 observations. The measures are calculated from the Industrial Statistics compiled by the United Nations Industrial Development Organization (UNIDO), using the between-groups component of Theil's T statistic, calculated across industrial sectors. Extensive testing of this data set against familiar alternatives with less coverage-the Luxembourg Income Studies and the World Bank's Deininger and Squire data set-shows it to be a reliable index both of differences in inequality levels between countries and of changes through time, and a good instrument for income inequality where these are reliably observed (Galbraith and Kum 2005). Detailed discussion of the construction of long and dense time-series of inequality using Theil's T measured across grouped data can be found in Conceição and Galbraith (2000) and Conceição, Galbraith and Bradford (2001).

The UTIP data provide support — elusive in other recent research - for the venerable Kuznets hypothesis of a downward sloping relationship between equality and per capita GDP in the midand later stages of industrial development. They are consistent with Kuznets' view that the evolution of inequality results primarily from intersectoral transitions, preeminently from agriculture to industry. They also suggest that inequality rises with income in some of the most advanced countries, a proposition Conceição and Galbraith (2001) have denoted the "augmented Kuznets hypothesis," which they associate with the provision of advanced technology goods to world markets, hence a pro-cyclical bent in the movement of inequality.

Thus, in the range in which most countries fall, lower economic inequality is associated to some extent with greater industrialization and with higher income levels, both of which might be presumed to confer military advantage. We will not attempt here to disentangle these influences, although we can easily point to examples-Vietnam leaps to mind--where the more egalitarian country prevailed in war despite having a lower income and little industry. Our interest is not so much in the mechanisms relating inequality to military effectiveness - we have already identified three separate channels whereby egalitarianism per se may affect military performance, and see no need to distinguish between them. Rather, our concern is with the usefulness of the measure as a marker for victory in war. 
The UTIP data set permits pairwise cross-country comparisons of inequality as far back as 1963 . However the characteristic patterns revealed by the data set may be used to infer the relative degree of inequality in a wide variety of cases going back at least to the middle of the $18^{\text {th }}$ century. For relatively recent decades, absent compelling reasons to think otherwise, we can simply assume that the relationships prevailing in the UTIP data were also those at the time of war. For earlier periods, we will refer to the traditional Kuznets hypothesis and historical sources, and associate known characteristics of the warring societies with relative egalitarianism as revealed in the UTIP data for modern times.

For instance, political variables are strongly associated with inequality in the UTIP data. Therefore, for earlier years we shall generally believe republics to be more egalitarian than monarchies and empires. We generally believe democratic republics to be more egalitarian than the fascist variety, and social democracies more egalitarian still. We shall hold the communist states, from 1917 forward, to be (to have been) the most egalitarian of all. (Military effectiveness is of course not the only criterion for system survival.)

\section{Equality and Victory 1963-1999}

We examine 32 international conflicts between recognized states from 1962 to present. For each conflict, we use the UTIP measure of pay inequality for the year the conflict ended, or the year the state exited the conflict. Of 32 conflicts and 42 potential pairwise comparisons (in the cases of multi-party wars), we present data for 23 conflicts and 31 match-ups. Where data are only available for years other than the year the conflict ceased, we impute data to the ending year from the nearest available measurement. Of the 31 comparisons, 13 use imputed data. The median distance from which these data are imputed is 2 years. ${ }^{4}$

Figure 1 shows the results of these comparisons. Of the 31 conflict pairs analyzed, the wage distribution was more equal in the winning country in 23 cases. A directional Wilcoxon signed rank test for the statistical significance of this relationship shows hat the relationship between the equality of the state and victory is statistically significant at the alpha $=0.001$ level $(\mathrm{Z}=-3.258)$.

A substantial share of the measurable conflicts represents pairings in the Middle East, with Israel on one side and various Arab states on the other. In the early days, Israel had a strong collective tradition, and it prevailed repeatedly against larger but highly inegalitarian monarchies and oligarchies in the surrounding region. More recently, the adversary Israel faces has become ascetic and egalitarian in ways that emulate the distant past of Zionism, while Israel has experienced one of the largest proportionate increases in inequality observed anywhere in the world. Meanwhile Israel's comparative military effectiveness has clearly declined: it was chased from South Lebanon by Hezbollah, and it shows no sign of overcoming Palestinian resistance to its occupation of the West Bank and Gaza, the effective leadership of which has now passed from the autocratic Al-Fatah movement to the egalitarian and ascetic Hamas.

\footnotetext{
${ }^{4}$ We exclude one conflict, the Mauritanian-Senegalese Border War, due to an 11-year gap in available data.
} 


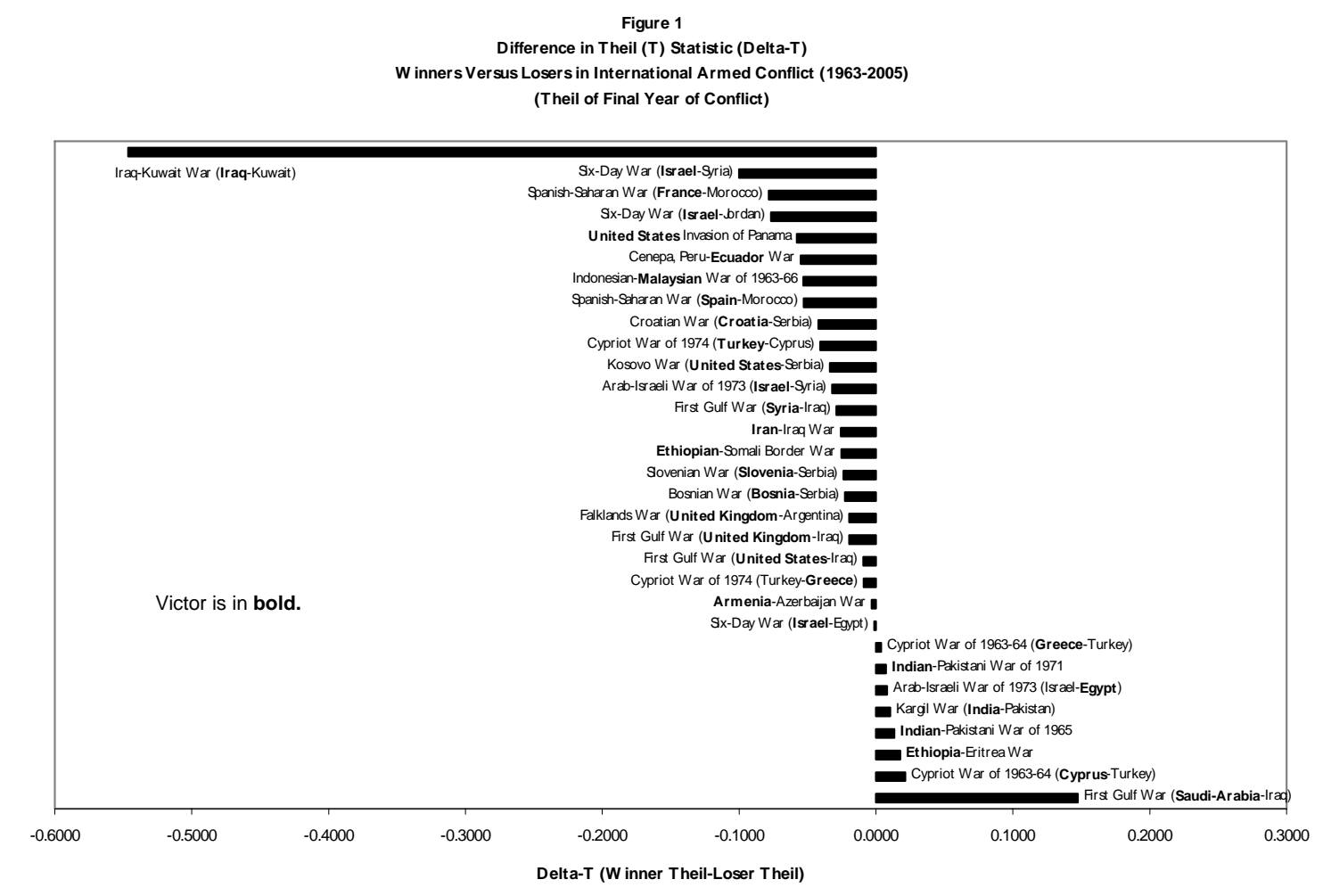

The value of this approach is demonstrated by the fact that in 13 of the 31 comparisons (42 percent of the total), the democratic victory thesis is unable to make a prediction because neither of the belligerents was democratic. Of these 13 cases, the equality thesis correctly predicted $11 .^{5}$ A directional Wilcoxon signed rank test for this relationship shows that it is statistically significant at the alpha $=0.01$ level $(Z=-2.359)$.

A democracy was involved in 15 of the 32 interstate conflicts during the study period and accounted for 20 of the 42 potential pairwise comparisons. In this match-up the income inequality thesis has better coverage, but its predictive accuracy is lower than "democratic victory." In particular, the democratic victory thesis correctly predicts the winner of the three India-Pakistan conflicts, and the equality thesis does not.

Table 1

Comparison of the Democratic and Equality Victory Theses

\begin{tabular}{llll} 
& $\begin{array}{l}\text { Conflict } \\
\text { Coverage }\end{array}$ & $\begin{array}{l}\text { Pairwise } \\
\text { Coverage }\end{array}$ & $\begin{array}{l}\text { Correct } \\
\text { Prediction }\end{array}$ \\
\cline { 2 - 4 } $\begin{array}{l}\text { Democratic Victory } \\
\text { Thesis }\end{array}$ & $(15 / 32) 47 \%$ & $(20 / 42) 48 \%$ & $(20 / 21) 95 \%$ \\
Equality Thesis & $(23 / 32) 72 \%$ & $(31 / 42) 74 \%$ & $(23 / 31) 74 \%$
\end{tabular}

\footnotetext{
${ }^{5}$ The incorrectly predicted cases were Saudi Arabia versus Iraq in the First Gulf War and Ethiopia versus Eritrea.
} 
But even in the India-Pakistan cases, the final judgment is not clearly adverse. For, what is the correct measure of inequality for Pakistan in 1965 and 1971? While the UTIP measures find that both West and East Pakistan are more equal than India, the substantial income gap between them is unaccounted for in our calculations. Adding in the West-East differential for Pakistan before the birth of Bangladesh at the end of the 1971 war might reverse the verdict as to which combatant was the more egalitarian. ${ }^{6}$

Of the other incorrect predictions, two relate to Cyprus and one pairing (Saudi Arabia-Iraq in 1991) pits a country that was a minor player in a war decided by the armed forces of the United States, which at that time was substantially more egalitarian than Iraq.

\section{Analysis of Conflict Pairs with Missing Data}

Table 2 displays the 11 conflict pairs for which we are missing data from at least one party. Of these pairs, six (Grenada, the 2001 Afghanistan War, the United States and South Vietnam versus North Vietnam, and the United States and the United Kingdom in the Second Gulf War) were won by the more equal state(s), so far as we are able to determine. In three cases (the Kampuchean-Thai border war, the Sino-Vietnamese war, and the Ossetian War) the more equal state is unclear. In two cases (the Libyan-Egypt War and the Mauritania-Senegal Border War) both the more equal state and the victor are unclear. In no case is there clear evidence of the less equal state winning the war. Adding the six predicted pairs to the Correct Prediction column in Table 1 would raise the predictive efficiency of the equality hypothesis to 78 percent.

Table 2

\section{List of Conflict Pairs with Missing Data}

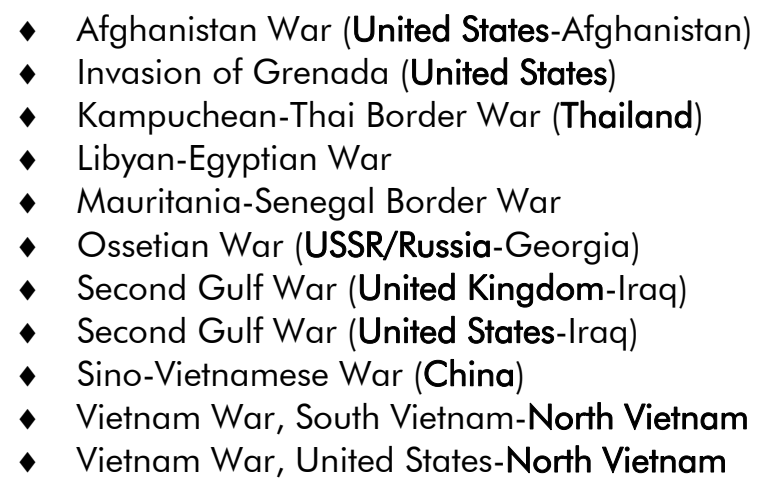

Note: The Second Gulf War ended in 2003. Conflict since the fall of the Ba'athist regime is counted as Iraq Civil War (2003-Present); however this classification is arbitrary and debatable. Bold indicates victor.

Reiter and Stam offer a total of 34 conflicts between 1816 and 1990 in which democracies participated on one side; of these democracies prevailed in 26, or 74 percent (p. 29). Thus in their analysis (as opposed to our matched sample of conflict pairs), the predictive force of the

\footnotetext{
${ }^{6}$ We thank Steve Marglin for calling attention to this point.
} 
democratic form of government is not any greater, and may be slightly less, than that of the egalitarian victory hypothesis. It is only when Reiter and Stam distinguish between initiators and targets in warfare that the percentage of democratic victories rises to 93 percent, or 14 cases out of 15. Since wars always involve a more equal and a less equal contestant, the egalitarian victory hypothesis disregards the distinction between initiator and target, which we regard in any event as overly open to manipulation to be entirely trustworthy.

In sum, an analysis of the best available data for equality shows that it is a strong predictor of success in interstate warfare. This analysis also shows that equality applies successfully to a larger universe of cases than the democratic victory thesis, and its predictive power is at least equally good, if one disregards the initiator/target filter.

\section{Equality and Victory: 1715-1962.}

On a more speculative note, we next offer selected cases of major wars in the modern period, with brief comments on the relative equality of the two sides.

With few exceptions, prior to modern national income accounting the inequality measures that we favor are unavailable. Yet, given the Kuznets relationship, information on the degree of industrial development, on quantities and types of imports and exports, and on population shares engaged in manufacturing and agriculture are able to reveal degrees of economic stratification (Williamson 1991). Social and religious stratification are also good proxies for economic inequality, especially in the early modern period. For instance, though the distribution of household income cannot be estimated from extant sources, we do know that Manipur adopted a highly stratified caste system in the centuries prior to their disastrous wars with Burma. Burmese society was largely pastoral with relatively egalitarian land tenure (Harvey 1967, pp. 228-42; Lieberman 2003; Reid 1990).

In the history of this period we encounter the upward-sloping section of the Kuznets curve. The early stages of industrial development and growth generate increased economic inequality as the economy segments into agricultural and (much wealthier) urban elements (Kuznets 1955; see also Williamson 1985, 1989; and van Zanden 1995). For pre-industrial and industrializing societies, the Kuznets relationship has been shown to be highly predictive of inequality (Williamson 1991), provided that the agricultural sector consists of small free-holds, as it did in (say) the northern United States before the Civil War. Kuznets would no doubt have taken a different view of latifundial or slave economies.

\section{Summary Statistics}

We first extend our analysis to 1816, if only for the reason that previous explanatory models also benchmark their analyses to that year, Napoleon having been vanquished for good in 1815 . Later, we delve further into history, testing our hypothesis in an era when democracies did not go to war, because there were no democracies at all.

We examined 80 international interstate conflicts between 1816 and 1962. A number of the conflicts involved dozens of state actors. For these, we counted only those most crucial to the 
conflict (for instance, Argentina or Uruguay in the Second World War did not make the list). We do not compare contestants pairwise as coalitional wars would comprise the majority of datapoints in our list, yet coalitional conflicts are about a quarter of all wars. The data would not support pairwise comparison, especially for the minor contestants.

In these years, the more equal side won 64 of the 80 conflicts ( 80 percent). The null hypothesis of no effect, or equal likelihood, gives a standardized score of $Z=-5.5(\alpha<0.0001)$.

Writing of Europe, van Zanden $(1995,650)$ holds, "the origins of the Kuznets curve must be located in the early modern period". Taking our analysis back a century further to 1716 , the pattern of egalitarian victory persists, with the more egalitarian states prevailing in 92 percent of cases. Of the 26 one-on-one conflicts, just five contestants (Russia, Spain, Burma, Persia, and Great Britain) participated in all but two. Seven one-on-one conflicts pitting Siam against in turn Burma, Vietnam, and Laos, are excluded for lack of conclusive historical information (see Harvey 1967, 219-39; Terweil 1983, ix, 29-51).

Overall, the analysis gives the following results. From 1962 through 1999, the more egalitarian country prevailed in 31 of 42 pair-wise comparisons. From 1816 to 1962, restricting our attention to bi-national wars, the more egalitarian country prevailed in 64 of 80 cases. From 1715 to 1815 , the proportion was 24 of 26 . Taking all together, we find the presumptively more egalitarian country prevailed in 119 of 148 cases. The appendix provides a list of covered conflicts.

\section{Selected Cases}

The case of Oriental despotism-as far as possible from modern-day democracy-epitomizes several key elements of our argument. In its purest form, oriental despotism is an absolutist monarchy admitting only one person superior in rank. Economic inequality can, however, vary greatly within these societies. During the early modern period, the often-warring Afghans, Persians, and Ottomans all shared a despotic-monarchical structure (Issawi 1984). However, in terms of degree of social and economic stratification, they differed, and this is borne out in their relative success at war.

The Afghan and Persian kingdoms followed what Machiavelli called the maxims of Eastern princes: they "stretch[ed] [the king's] authority so far as to leave no distinction of rank among his subjects but what proceeds immediately from himself: no advantages of birth, no hereditary honors and possession...." In contrast, the Ottoman state behaved like other European states, "leav[ing] other sources of honor besides his smile and favor" (Hume 1953, 17-18).

In part because of the failure of the Osmanli dynasty to produce sane, competent sultans, and in part to facilitate commerce, the Ottoman Empire adopted an extensive bureaucratic state. Originally the gloved hand of oriental despotism, the bureaucracy gained increasing autonomy, diluting the Porte's political power. In the process of political leveling, the bureaucrats also introduced lucrative monopolies and guilds, creating gross economic and social inequalities (Baer 1970). 
Findley (1986) tallied payroll accounts from the Ottoman state and found mean wages for bureaucrats far exceeded medians, as expected under the Tanzimat elite (see also Issawi, 1980). Thus the Ottoman Empire was highly inegalitarian. The Ottoman Turks lost 14 of the 19 wars in our dataset, with each loss delivered by more egalitarian hands.

Persia perfected Oriental despotism under the rulership of a Shah, or 'King of Kings.' In both his Persian Letters (1721) and The Spirit of the Laws (1748), Montesquieu used Persian rulership as the archetype for absolutism. However, Persian society was economically egalitarian throughout most of the $18^{\text {th }}$ and $19^{\text {th }}$ centuries (Lambton, 1953; Abrahamian, 1974). Persia's earlier Safavid dynasty (1501-1736) collapsed due to its inability to balance internal and external security. The Safavid court's great opulence undermined traditional tribal loyalties upon which their power really rested.

The Safavid dynasty's successors, the Qajars, dealt with the same diffuse tribes, poverty, and historical enemies, along with a new rival, the Russians. Despite these disadvantages, Qajar Persia's fighting prowess actually increased. Unlike their predecessors, the Qajar kings, tribal leaders and officials did not enrich themselves relative to the masses and lived side-by-side with them (Lambton 1953). In fact, the Qajars had no standing army whatsoever. As one Shah boasted, "I have neither an army nor the ammunition to supply an army" (Abrahamian 1974, 11). Yet Persia was among the most victorious of the large powers, winning 6 of 8 wars from 17161816.

The later Qajar shahs attempted to consolidate their power at the expense of their various tribes. In doing so, they increased the size of the bureaucracy and the military, polarizing Persian society into a military and bureaucratic elite, on the one hand, and traditional tribal and agricultural populations on the other (Gilbar 1978). From 1828-1911, Persia's military fortunes reversed, with Persia losing all five of the wars in which she fought.

The canonical debut of the modern republic comes with the creation of the American and the French revolutions, both of which were immediately cast into wars against imperial opponents using, in part, mercenary forces. The republic founded on the idea that "all men are created equal" fought its way to victory in 1783, while that founded on "Liberté, Egalité, Fraternité" achieved surprising victory over multiple enemies in 1799. The fledgling United States then suffered ignominious defeat in even-more-egalitarian Canada in 1812, before redeeming itself in battle at New Orleans against the British on January 8, 1815, in a battle in which Creoles and free men of color were deeply engaged.

Meanwhile France had regressed from Republic to Empire, and as Napoleon became more imperial he became less militarily effective; as early as 1803 he was beaten in Haiti by the selffreed slaves of Toussaint L'Ouverture. It is impossible from the present remove to judge the relative equalities of (say) France and Russia as a whole in 1812, but it is very plausible to argue that the French Empire, whose Grande Armée was drawn heavily from Poland and other Slavic lands, was less egalitarian than the Cossacks it faced at Borodino. It is even more probable that the France of 1815 was less egalitarian than the British, if not the Prussians, that Napoleon faced at Waterloo. 
The American Civil War was, from the point of view of both sides, a conflict between territorial entities with well-defined borders. The Confederacy considered itself to be, and in 1860 for practical purposes was, an independent nation state. It was also a slave-owners' oligarchy, commanding the loyalty neither of its black slaves nor of many of its property-less white settlers, especially in such regions as Western Virginia (which seceded from Virginia in order to stay in the Union), and eastern Tennessee (from which Lincoln's 1864 running mate, Andrew Johnson, was chosen). The Union, on the other hand, was a land of relatively small farmers and an emerging industrial working class; by 1864 it was arguably (after Haiti) the most egalitarian republic in history. Karl Marx saw the social difference clearly, and in early 1865 penned his famous letter of congratulation to Abraham Lincoln, which begins, "From the commencement of the titanic strife, the workingmen of Europe felt instinctively that the star spangled banner carried the destiny of their class." Enough said on that score.

In the 1850s, the rising bourgeois states of France and Britain defeated the decaying Russian Empire in the Crimea. In 1870, France was beaten by Prussia in a lightning campaign that ended at Sedan. Prussia was at that time an emerging industrial power; but by 1870 France had been a retrograde empire under Napoleon II for two decades. By 1914, on the other hand, France had been a republic for 44 years, and its industrial development had progressed to a point comparable to Germany's, though in a smaller country. A strong socialist workers' movement had by then emerged; arguably France in 1914 was at least as egalitarian as the German empire. The comparison with the United Kingdom is less clear, but in any event the result on the Western Front was stalemate to the point of exhaustion, resolved only by the intervention in 1917 of that relatively egalitarian republic, the United States. On other World War I fronts, Germany was surely more egalitarian than Tsarist Russia, which collapsed early in the war. The decrepit Ottoman Empire was a major casualty of the war, but on the other hand the secular, nationalist and relatively egalitarian Turkey that emerged from its ruins proved highly effective against the British at Gallipoli, and in driving the Greeks from Asia Minor in the immediate aftermath of the war.

From 1932-1935 Bolivia defeated Paraguay in a bloody conflict known as the Chaco Wars. According to the UTIP data, Paraguay is today the most unequal country of Latin America and one of the most unequal in the world; Bolivia (alongside fellow-combatants Argentina and Brazil) are unequal but less so.

France suffered the Great Depression severely, something that the UTIP data teach us is almost certain to generate rising inequality (see for instance, Calmon, Conceição, Galbraith and Garza, 2000). Though France did elect a Popular Front government in 1936, it did not engage in the broad spectrum of expansionary policies and military rearmament that returned Germany to full employment in the late 1930s. By 1940, relative inequality in France would likely have risen very sharply, while that in Germany almost surely declined in the early years of Nazi rule. Germany was probably not more egalitarian than Czechoslovakia in 1938, and it is a tragedy of history that the Czechoslovaks were betrayed and chose not to defend themselves. Germany in 1939 was, on the other hand, probably more egalitarian than aristocratic Poland. Certainly on the other side the Soviet Union was more egalitarian than Poland by that point. 
In 1905, Japan was a rising industrial power and a cohesive state, facts which enabled Japan to make mincemeat of the Russian Navy before Port Arthur. Japan was also surely a more egalitarian state than the China it invaded in 1933, and of which it had conquered large portions before initiating conflict with the United States in December of 1941.

World War II proper presents a plethora of comparisons. Perhaps the most important are the USSR against Germany, the United States against Japan, the United States against Germany and Italy, and Great Britain against Germany. In all of these, we believe, the plausible case is that the more egalitarian country prevailed. As Galbraith and Ferguson (2001) have shown, war mobilization in the United States produced a radical leveling of the wage and income structure within a year after the start of the war. Something similar undoubtedly happened in Britain, though not in Germany where social structures were rigorously preserved by the Nazis and women excluded, largely, from the industrial workforce.

The Korean War of 1950-1953 provides a very interesting case, insofar as both halves of the peninsula were cut from the same cloth at that time, while the newly-established People's Republic of China and the United States were then both among the world's most egalitarian countries. The result of the war — not surprisingly from the standpoint of our hypothesis — was a rare draw.

In the wars of the 1950s, nationalists in Vietnam and Algeria chased the French from their colonies. France was a moderately egalitarian democratic republic in those days but the Vietnamese and Algerians, though not democratic, were surely more egalitarian. Similarly the (democratic) Dutch were forced to exit (undemocratic) Indonesia, where a strong communist presence continued until it was savagely extinguished in $1965 .^{7}$ In 1961 , in a small engagement, a lightly-armed Cuban militia defeated a CIA-backed brigade of exiles at the Bay of Pigs. In 1962, the Chinese People's Liberation Army made short work of the Indian forces defending the Northeast Frontier Agency and Ladakh. In all of these cases, the more egalitarian side prevailed, notwithstanding a much weaker industrial system and lower per capita income. In each of these cases, egalitarian victory occurred despite the fact that in most of these cases the losing party would qualify as a democracy while the winning side would not.

What is truly striking about all this is not how easy it is to make a plausible argument for the thesis that the more egalitarian power usually prevailed in conflict, notwithstanding adverse differences in average income level, industrial development or democratic status. What is truly striking is, rather, how difficult it is to identify unmistakable opposing cases. Unambiguous cases of the inegalitarian state prevailing in major bi-national conflict between modern nation-states undoubtedly exist. But aside from India versus Pakistan we have not been able to find them. And looking at a list of wars in this period reveals very few instances where one is tempted to dig deeply for further evidence.

\footnotetext{
7 And while the British put down an insurrection in Malaya and the U.S. helped suppress one in the Philippines, in neither of those cases did the insurrection constitute a full-fledged national movement.
} 


\section{Classical Cases: Athens to Agincourt}

The saga of the Peloponnesian wars provides a cautionary tale, known to all school-children, of the contest of democracy against a hyper-egalitarian martial state. Reiter and Stam quote Herodotus on the rise of Athens, but while they take him to be speaking of popular government, equality is the word he actually uses:

"It is not only in respect of one thing but of everything that equality and free speech are clearly a good; take the case of Athens, which under the rule princes proved to be no better in war than any of her neighbors, but once rid of those princes, was far the first of all." (Reiter and Stam, 61) Very curiously, the index of Democracies at War contains no entry for Sparta.

The Punic Wars are a bit harder to read, as both Rome and Carthage were empires, though the former had been a republic and the reach of the latter was greater, making it possibly less egalitarian on both counts. The decline and fall of the Roman empire is another school tale; by the time Alaric sacked Rome in AD 410 it was surely far less egalitarian than its attackers. Indeed, Procopius of Caesarea gives an account of just how the inequalities of Rome led to its capture:

"Among the youths in the army whose beards had not yet grown, but who had just come of age, [Alaric] chose out three hundred whom he knew to be of good birth and possessed of valor beyond their years, and told them secretly that he was about to make a present of them to certain of the patricians in Rome, pretending that they were slaves. And he instructed them that, as soon as they got inside the houses of those men, they should display much gentleness and moderation and serve them eagerly in whatever tasks should be laid upon them by their owners; and he further directed them that not long afterwards, on an appointed day at midday, when all those who were to be their masters would most likely be already asleep after their meal, they should all come to the gate called Salarian and with a sudden rush kill the guards, who would have no previous knowledge of the plot, and open the gates as quickly as possible." (Procopius 1953-4)

Neither Rome nor Carthage figure in the index to Reiter and Stam.

Like the armies of Alexander, the Golden Horde of Tamurlane, Genghis Khan and Attila owed their vast military success in part to a comparatively flat hierarchy; nomadic tribes everywhere are more broadly egalitarian than the domains they ravage. The Moghul conquest of India provides an even stronger case, for it was a religious war, in which the Islamic armies from the North repudiated the Hindu caste system that they faced. Islam won its Indian converts heavily from the lowest castes.

The Spanish conquest of the Americas likewise took advantage of divisions in the deeply hierarchical territorial empires that the small bands of Cortes and Pizarro stumbled into. On the other hand, few would doubt that Elizabethan England was more egalitarian than the Spain of 
Philip II; Sir Francis Drake epitomizes the rise of the common privateer on merit rather than birth.

Our final example is perhaps the most clear-cut. At Agincourt, the British triumph rests in the historical record on the military effectiveness of the Welsh longbowmen - a yeomen's cohort with no equivalent in the French army. We also have the immortal encounter of King Hal, in disguise, with Pistol, on Crispin's Eve:

PISTOL

Discuss unto me; art thou officer?

Or art thou base, common and popular?

KING HENRY V

I am a gentleman of a company.

PISTOL

Trail'st thou the puissant pike?

KING HENRY V

Even so. What are you?

PISTOL

As good a gentleman as the emperor.

KING HENRY V

Then you are a better than the king.

\section{Conclusion}

Democracies are generally speaking egalitarian in comparison with most other forms of government, and so the hypothesis of democratic victory has a certain amount in common with the hypothesis of egalitarian victory. Where the cases overlap, they explain many of the same things and for similar reasons. However, we have demonstrated that a focus on equality carries substantially more persuasive power, for at least the following reasons:

First, few combatants qualify as democracies, and among those that do, the claim of democratic status is often contestable. Democracy is, after all, an ideal type. The accepted indicators of democracy are a complex scale of attributes, subject to methodological variation (such as different weightings on different attributes) that might conceivably change the rankings. On the other hand, all wars are in principle between more and less egalitarian combatants. Measurements of inequality done in the manner prescribed are standard and uniform from one country to the next, leaving little room for method-driven variations. 
Second, the hypothesis of democratic victory relies heavily on an accurate distinction between initiators and targets. But this too is problematic and contestable ground. On the other hand, the hypothesis of egalitarian victory focuses on conditions at the moment of military decision, and expresses no interest in how a war may have begun.

Third, where direct measurement is available in the modern period, the egalitarian victory hypothesis accurately predicts the outcome in a wide majority of cases.

Fourth, it is possible to make reasonable conjectures about relative inequality for a wide range of earlier wars. While it is always possible that this exercise is contaminated by prior knowledge of the victors, in many cases the differences in social system are so stark as to make the direction of difference, if not its magnitude, reasonably clear-cut. For many earlier wars literary and historical evidence can be found; indeed the commentary on the importance of solidarity in military effectiveness and the rot that sets in with wealth and hierarchy is virtually omnipresent in classical discussions of military outcomes. In virtually all of these cases, lore and legend hold that the more egalitarian society is likely to prevail.

Fifth and finally, there have been a handful of wars in which democracies were pitted against states more egalitarian than themselves, providing a discriminating test of the two conjectures. These were the twentieth century's wars over communism: among them the Allied expedition to Archangel in 1920, the Korean War, and the Vietnam War. In all of these cases the communist country prevailed (or, in the case of Korea, fought a much richer and more powerful country to a draw). In fact, there appears to be no case in which a communist country, however small or underdeveloped, suffered ultimate military defeat at the hands of any less egalitarian state.

All of this raises questions that ought to be disturbing to those who believe a free-market economic order can be combined with sustained military dominance in the modern world. The Iraq war notably features an occupying power that has seen inequality rise dramatically since the days of its greatest martial glory a half century ago. The American military is under obvious stress from this fact, for the simple reason (among others) that as a career it cannot compete for the services of the prosperous. On the other side, the Iraq of 2003 was a highly unequal country of Sunni overlords and rebellious Shiite underlings. But the Iraqi insurgency of 2006 represents an egalitarian mini-state in central Iraq, directed by a very effective secret police. From the standpoint of the egalitarian victory hypothesis, it is no surprise to us that the tables have turned. 


\section{REFERENCES AND SELECTED BIBLIOGRAPHY:}

Abrahamian, Ervand. 1974. "Oriental Despotism: The Case of Qajar Iran." International Journal of Middle East Studies 5(1):3-31.

Acemoglu, Daron, and James A. Robinson, 2006. The Economic Origins of Dictatorship and Democracy. New York: Cambridge University Press.

Ahmad, Feroz. 1980. "Vanguard of a Nascent Bourgeoisie: The Social and Economic Policy of the Young Turks." In Osman Okyar and Halil Inalcik, eds. Social and Economic History of Turkey. Ankara: Hacettepe University Press.

Aliboni, Roberto. 1979. Arab Industrialization and Economic Integration. London: St. Martin's Press.

Almadovar, Antonio. 1998. A History of Portuguese Economic Thought. London: Routledge.

Ashtor, E. 1976. A Social and Economic History of the Near East in the Middle Ages. Berkeley and Los Angeles: University of California Press.

Baer, Gabriel. 1970. "Monopolies and Restrictive Practices in Turkish Guilds." Journal of the Social and Economic History of the Orient 13(1): 145-65.

Bairoch, Paul. 1974. "Geographical Structure and Trade Balance of European Foreign Trade from 1800 to 1970." Journal of European Economic History 7:54-70.

Bairoch, P. and M. Levy-Leboyer. 1981. Disparities in Economic Development since the Industrial Revolution. New York: St. Martin's Press.

Bekele, Shiferaw. 1995. An Economic History of Ethiopia: The Imperial Era, 1941-74. CPLD.

Black, Cyril et al., eds. 1975. The Modernization of Japan and Russia. New York: Free Press.

Blainey, Geoffrey. 1988. The Causes of War, $3^{\text {rd }}$ ed. New York: Free Press.

Bohme, Helmut. 1978. An Introduction the Social and Economic History of Germany, 1800 to Present. New York: Palgrave Macmillan.

Bollen, Kenneth A. (1980) "Issues in the Comparative Measurement of Political Democracy.” American Sociological Review 45 (June): 370-90.

Bremer, Stuart A. (1992) "Dangerous Dyads: Conditions Affecting the Likelihood of Interstate War, 1816-1965.” Journal of Conflict Resolution 36 (2): 309-41. 
Brenner, Y. S., Hartmut Kaelble, and Mark Thomas. 1991. Income Distribution in Historical Perspective. Cambridge, MA: Cambridge University Press.

Bulmer-Thomas, Victor, John Coatsworth, and Roberto Cortes-Conde. 2005. The Cambridge Economic History of Latin America, 2 vols. Cambridge: Cambridge University Press.

Calmon, Paulo Du Pin, Pedro Filipe Teixeira da Conceição, James K. Galbraith, Vidal Garza-Cantú and Abel Hibert. 2000. "The Evolution of Industrial Wage Inequality in Mexico and Brazil." Review of Development Economics 4(2): 194-203.

Cameron, Rondo and Larry Neal. 2002. A Concise Economic History of the World from Paleolithic Times to the Present, $4^{\text {th }}$ ed. New York: Oxford University Press.

Caron, Francois. 1979. An Economic History of Modern France. New York: Columbia University Press.

Cipolla, Carlo M. 1994. Before the Industrial Revolution: European Society and Economy, 1000-1700, $3^{\text {rd }}$ ed. New York: W.W. Norton.

Conceição, Pedro and James K. Galbraith. 2000. "Constructing Long and Dense Time Series of Inequality Using the Theil Statistic.” Eastern Economic Journal 26(1): 61-74.

Conceição, Pedro, James K. Galbraith and Peter Bradford. 2001."The Theil Index in Sequences of Nested and Hierarchical Grouping Structures: Implications for the Measurement of Inequality Through Time, With Data Aggregated at Different Levels of Industrial Classification.” Eastern Economic Journal 27(4): 491-514.

Dower, John. 2000. Embracing Defeat. New York: W.W. Norton.

Dumke, Rolf. 1991. "Income Inequality and Industrialization in Germany, 1850-1913: The Kuznets Hypothesis Re-Examined,” in Brenner et al., pp. 117-148.

Falkus, Malcolm E. 1972. The Industrialization in Russia, 1700-1914. London: Macmillan.

Fields, G. S. 1980. Poverty, Inequality, and Development. Cambridge: Cambridge University Press.

Findley, Carter Vaughn. 1986. "Economic Bases of Revolution and Repression in the Late Ottoman Empire.” Comparative Studies in Society and History 28:81-106.

Flora, P. et al. 1987. State, Economy and Society in Western Europe 1815-1975, 2 vols. Cambridge: Cambridge University Press. 
Floud, Roderick and Deirdre McCloskey. 1994. Economic History of Great Britain since 1700, vol. $1,2^{\text {nd }}$ ed. Cambridge: Cambridge University Press.

Fox-Stuart, Martin. 1997. A History of Laos. Cambridge: Cambridge University Press.

Galbraith, James K. and Hyunsub Kum. 2005. "Estimating the Inequality of Household Incomes: Toward a Dense and Consistent Global Data Set."_Review of Income and Wealth, Series 51(1):115-143.

Geller, Daniel. 1985. Domestic Factors in Foreign Policy. Cambridge, MA: Schenkman.

Geller, Daniel, and J. David Singer. 1998. Nations at War. Cambridge, UK: Cambridge University Press.

Gilbar, Gad. 1978. "Persian Agriculture in Late Qajar Persia." Asian and African Studies $11: 2$.

Glamann Kristof. 1958. Dutch-Asiatic Trade, 1620-1740. Copenhagen: Danish Science Press.

Hale, Travis. 2004. “Theoretical Basics of Popular Inequality Measures.” University of Texas Inequality Project tutorial, http://utip.gov.utexas.edu/tutorials/theo basic ineq measures.doc

Hanneman, R. A. 1980. "Income Inequality and Economic Development in Great Britain, Germany, and France: 1850 to 1970." Comparative Social Research 3: 175-84.

Harrison, Mark. 1998. "The Economics of World War II: an Overview," in Mark Harrison, ed., The Economics of World War II: Six Great Powers in International Comparison, Cambridge University Press.

Henderson, Errol A. 2002. Democracy an War: The End of an Illusion? Boulder, CO: Lynne Rienner Publishers.

Hirschleifer, Jack. 2001. The Dark Side of Force: Economic Foundations of Conflict Theory. New York: Cambridge University Press.

Hirschman, A. O. and M. Rothschild. 1973. "The Changing Tolerance for Income Inequality in the Course of Economic Development." Quarterly Journal of Economics 87:544-66.

Hume, David. 1953. Political Essays. New York: Anchor.

Issawi, Charles. 1970. "Middle East Economic Development, 1815-1914.” In M. A. Cook, ed. Studies in the Economic History of the Middle East. London: Oxford University Press. 
Issawi, Charles. 1980. "Wages in Turkey, 1850-1914." In Osman Okyar and Halil Inalcik, eds., Social and Economic History of Turkey. Ankara: Hacettepe University Press.

Issawi, Charles. 1982. An Economic History of the Middle East and North Africa. New York: Columbia University Press.

Kahan, Arcadius. 1985. The Plow, The Hammer, and The Knout: An Economic History of Eighteenth Century Russia. Chicago: University of Chicago Press.

Kaldor, Nicholas. 1946. "The German War Economy." Review of Economic Studies 13: 33-52.

Kapstein, Ethan B. 2003. "Two Dismal Sciences Are Better Than One-Economics and the Study of National Security." International Security 27 (3):158-87.

Kennedy, Paul M. 1987. The Rise and Fall of the Great Powers: Economic Change and Military Conflict from 1500 to 2000. New York: Random House.

Kuznets, S. 1953. Shares of Upper Income Groups in Income and Savings. New York: National Bureau of Economic Research monograph.

Kuznets, S. 1955. "Economic Growth and Income Inequality." American Economic Review 45:1-28.

Lambton, A. K. S. 1953. "Persian Trade under the Early Qajars." In D. S. Richards, Islam ad the Trade of Asia. Oxford: B. Cassirer.

Lieberman, Viktor. 2003. Strange Parallels: Southeast Asia in Global Context, c. 8001830. Cambridge: Cambridge University Press.

Lindert, Peter H. 1985. "Growth, Equality, and History.” Explorations in Economic History 22:341-71.

Lindert, Peter. 1991. "Toward a Comparative History of Income and Wealth Inequality," in Brenner et al. (eds.), pp. 212-230.

Lockwood, William. 1954. The Economic Development of Japan. Princeton, NJ:

Princeton University Press.

Magnusson, Lars. 2000. An Economic History of Sweden. London: Routledge.

Maoz, Zeev and Nasrin Abdolah. 1989. "Regime Types and International Conflict, 18161976," Journal of Conflict Resolution 33 (March): 3-35. 
Mitchell, B. R. 1986. European Historical Statistics, 1750-1970, $2^{\text {nd }}$ ed. New York: Columbia University Press.

Mosse, W. E. 1996. An Economic History of Russia, 1856-1914. Boston: I.B. Tauris.

Olson, Mancur and Richard Zechhauser. 1966. "An Economic Theory of Alliances." Review of Economics and Statistics 48 (3): 266-279.

Overy, R. J. 1994. War and Economy in the Third Reich. New York: Oxford University Press.

Pirenne, Henri. 1956. Economic and Social History of Medieval Europe. New York: Harvest Press.

Prest, A. R. 1948. War Economics of Primary Producing Countries. Cambridge: Cambridge University Press.

Pribram, A. F. 1938. Materialien zur Geschichte der Preise und Löhne in Österreich. Vienna.

Price, Roger. 1981. An Economic History of Modern France, 1730-1914. London: Palgrave Macmillan.

Procopius, History of the Wars, 7 vols., trans. H. B. Dewing (Cambridge, Mass., and London: Harvard University Press \& Wm. Heinemann, 1914; reprint ed., 1953-54), II.1123. Scanned and modernized by: J. S. Arkenberg, Dept. of History, Cal. State Fullerton.

Reid, Anthony. 1990. Southeast Asia in the Age of Commerce, 1450-1680: Vol. 1: The Lands below the Winds. New Haven: Yale University Press.

Reid, Anthony. 1995. Southeast Asia in the Age of Commerce, 1450-1680: Vol. 2: The Age of Expansion. New Haven: Yale University Press.

Ringrose, David. 1983. Madrid and the Spanish Economy, 1560-1850. Berkeley and Los Angeles: University of California Press.

Ringrose, David. 1998. Spain, Europe, and the 'Spanish Miracle', 1700-1900, rev. ed. Cambridge: Cambridge University Press.

Rostow, W. W. 1978. The World Economy: History and Prospect. Austin, TX: University of Texas Press.

Small, M. and J. D. Singer. 1976. "The War Proneness of Democratic Regimes, 18161965.” Jerusalem Journal of International Relations 1 (2): 50-69. 
Small, Melvin and J. David Singer. 1982. Resort to Arms: International and Civil Wars 1816-1980. Thousand Oaks, CA: Sage.

Soderberg, J. 1987. "Real Wage Trends in Urban Europe, 1730-1850: Stockholm in a European Perspective.” Social History 12: 155-76.

Soltow, L. 1989. "Income an Wealth Inequality in Amsterdam, 1585-1805." Economischen Sociaal-historisch Jaarboek 52: 72-95.

Soltow, L. 2001. "Inequality of Wealth and Income in the Netherlands at theBeginning of the Nineteenth Century." In J. L. van Zanden and L. Soltow, Income and Wealth Inequality in the Netherlands, $16^{\text {th }}-20^{\text {th }}$ Centuries. Amsterdam: Het Spinhuis.

Subrahmanyam, Sanjay. 1993. The Portuguese Empire in Asia, 1500-1700. Boston: Longman.

Terweil, B. J. 1983. A History of Modern Thailand, 1767-1942. St. Lucia, Queensland: University of Queensland Press.

Thomas, Mark. 1991. "The Evolution of Inequality in Australia in the Nineteenth Century.” In Brenner et al., eds., pp. 149-173.

Weede, Erich. 1984. "Democracy and War Involvement," Journal of Conflict Resolution 28 (4): 649-64.

Weede, Erich. 1992. "Some Simple Calculations on Democracy and War Involvement." Journal of Peace Research 29 (4): 377-83.

Williamson, Jeffrey G. and Peter H. Lindert. 1980. American Inequality: A Macroeconomic History. New York: Academic Press.

Williamson, Jeffrey G. 1982. "The Structure of Pay in Britain, 1710-1911.” Research in Economic History 7: 1-52.

Williamson, Jeffrey G. 1985. Did British Capitalism Breed Inequality? Boston: Allen \& Unwin.

Williamson, Jeffrey G. 1991. "British Inequality in the Industrial Revolution: Accounting for the Kuznets Curve," in Brenner et al. 1991, pp. 57-74.

Wintle, Michael. 2000. An Economic and Social History of the Netherlands, 1800-1920: Demographic, Economic, Social Transition. Cambridge: Cambridge University Press.

van Zanden, J. L. 1992. "Economic Growth During the Golden Age: The Development of the Economy in Holland, 1500-1650." Economic and Social History of the Netherlands 4:5-26. 
van Zanden, J. L. 1993. The Transformation of European Agriculture in the Nineteenth Century: The Case of the Netherlands. Austin, TX: Harry Ransom Research Center.

van Zanden, J.L. 1995. Tracing the Beginning of the Kuznets Curve: Western Europe during the Early Modern Period. The Economic History Review 48 (4): 643-664.

van Zanden, J. L., M. 't Hart, and J. Jonker, eds. 1997. A Financial History of the Netherlands. Cambridge: Cambridge University Press.

van Zanden, J. L. 2001. "Income and Wealth Inequality in Holland, 1500-1800.” In J. L. van Zanden and L. Soltow, Income Inequality in the Netherlands, $16^{\text {th }}-20^{\text {th }}$ Centuries. Amsterdam: Het Spinuis.

Zmora, Hillay. 2000. Monarchy, Aristocracy and State in Europe, 1300-1800. London: Routledge. 
Appendix: Wars, Victors, and Equality

\section{Conflicts}

Victor

Austro-Turkish War of 1716-18

Russo-Persian War of 1722-23

Persian-Afghan War of 1726-38

Turko-Persian War of 1730-36

Spanish-Portuguese War of 1735-37

Russo-Turkish War of 1736-39

Austro-Turkish War of 1737-39

Persian Invasion of Mogul India (1738-39)

Turko-Persian War of 1743-47

Carnatic War, First (1744-48)

Carnatic War, Second (1749-54)

Burmese-Manipuri War of 1755-58

Spanish-Portuguese War of 1762

Burmese-Manipuri War of 1764

Burmese-Chinese War of 1765-69

Catherine the Great's First War with the Turks (176874)

Burmese-Manipuri War of 1770

Dutch War of 1780-84

Catherine the Great's Second War with the Turks

\section{(1787-92)}

Persian-Afghan War of 1798

Russo-Persian War of 1804-13

Russo-Turkish War of 1806-12

Russo-Swedish War of 1808-9

Anglo-Dutch War in Java (1810-11)

Napoleon's Invasion of Russia (1812)

Algerine War (1815)

Persian-Afghan War of 1816

War of the Pacific (1821-37)

Argentine-Brazilian War of $1825-28$

Russo-Persian War of 1825-28

\section{Austria \\ Russia \\ Persia \\ Persia \\ Spain \\ Russia \\ Austria \\ Persia \\ Persia \\ Great Britain \\ Great Britain \\ Burma \\ Spain \\ Burma \\ Burma}

Russia

Burma

Great Britain

Russia

Persia

Russia

Russia

Russia

Great Britain

Russia

U.S.

Persia

Chile

Uruguay-Argentina

Russia
Defeated

Victor More

Ottoman Empire

Persia

Afghanistan

Ottoman Empire

Portugal

Ottoman Empire

Ottoman Empire

Moghul India

Ottoman Empire

France

France

Manipur

Portugal

Manipur

China

Ottoman Empire

Manipur

Holland

Ottoman Empire

Afghanistan

Persia

Ottoman Empire

Sweden

Holland

France

Spain

Afghanistan

Bolivia-Peru

Brazil

Persia
Victor More
Egalitarian?

1

1

1

1

1

1

1

1

1

1

0

1 
Miguelite Wars (1828-34)

Russo-Turkish War of 1828-29

Siamese-Cambodian War of 1831-34

Abd el-Kader, First War of (1832-34)

Turko-Egyptian War, First (1832-33)

Abd el-Kader, Second War of (1835-37)

Persian-Afghan War of 1836-38

Peruvian-Bolivian Confederation, War of the (1836-

39)

Pastry War (1838)

Turko-Egyptian War, Second (1839-41)

Afghan War, First (1839-42)

Opium War, First (1839-42)

Peruvian-Bolivian War of 1841

Siamese-Vietnamese War of 1841-45

Sikh War, First (1845-46)

Mexican War (1846-47)

Sikh War, Second (1848-49)

Anglo-Burmese War, Second (1852)

Turko-Montenegrin War, First (1852-53)

Crimean War (1853-56)

Walker's Invasion of Mexico (1853-54)

Persian-Afghan War of 1855-57

Walker's Invasion of Nicaragua (1855-57)

Anglo-Persian War of 1856-57

Opium War, Second (1856-60)

Spanish-Moroccan War of 1859-60

Civil War, U.S. (1861-65)

Mexican-French War of 1861-67

Turko-Montenegrin War, Second (1861-62)

Ecuadoran-Colombian War of 1863

Meiji Restoration (1863-68)

Shimonoseki War (1863-64)

Danish-Prussian War of 1864
Britain-France-Spain-Portuga

Russia

Siam

Algeria-Morocco

Egypt

Algeria-Morocco

Afghanistan

Chile

France

Ottoman Empire-Great Britain-

Russia

Afghanistan

France

Bolivia

Siam

Great Britain

U.S.

Great Britain

Great Britain

Montenegro

Western Powers

United States

Afghanistan

United States

Great Britain-Afghanistan

France-Great Britain-U.S.-

Russia

Spain

Union

Mexico

Ottoman Empire

Colombia

U.S.

France-Netherlands-Great

Britain-U.S.

Denmark \& Allies
Absolutists/Holy Alliance 1

Ottoman Empire 1

Cambodia

France

Ottoman Empire

France 1

Persia 1

Bolivia-Peru 0

Mexico

Egypt 0

Great Britain 1

China 0

Peru 1

Vietnam 1

Punjab

Mexico 1

Punjab 1

Burma 1

Ottoman Empire 1

Russia 1

Mexico 1

Persia 1

Nicaragua 1

Persia 1

China 0

Morocco

Confederacy 1

France 1

Montenegro 0

Ecuador 1

Tokugawa Shogunate 1

Japan 1

Prussia 
Paraguayan War (1864-70)

Spanish-Peruvian War of 1864-66

Seven Weeks' War (1866)

Franco-Prussian War (1870-71)

Ethiopian-Egyptian War of 1875-77

Serbo-Turkish War of 1876-78

Russo-Turkish War of 1877-78

Afghan War, Second (1878-80)

Pacific War

Boer War, First (1880-81)

Sino-French War of 1883-85

Guatemalan War (1885)

Russo-Afghan War of 1885

Serbo-Bulgarian War of 1885-86

Italo-Ethiopian War of 1887-89

Sino-Japanese War of 1894-95

Italo-Ethiopian War of 1895-96

Greco-Turkish War of 1897

Spanish-American War (1898)

Boer War, Second or Great (1899-1902)

Boxer Uprising (1899-1901)

Russo-Japanese War of 1904-5

Honduran-Nicaraguan War of 1907

Italo-Turkish War of 1911-12

Russo-Persian War of 1911

Balkan War, First (1912-13)

Balkan War, Second (1913)

World War I (1914-18)

Russo-Polish War of 1919-20

Greco-Turkish War of 1921-22

Northern Expedition (1926-28)

Chaco War (1932-35)

Italo-Ethiopian War of 1935-36

Sino-Japanese War of 1937-45

Russo-Finnish War of 1939-40

World War II (1939-45)

French IndoChina War of 1946-54
BRAZIL-Argentina-Uruguay

Peru-Bolivia-Ecuador

Prussian states-Italy

Prussia

Ethiopia

Ottoman Empire

Russia

Great Britain

Chile

South Africa (Boer Republic)

France

El Salvador

Russia

Bulgaria

Italy-Great Britain

Japan

Ethiopia

Ottoman Empire

S.

Great Britain

Western Powers

Japan

Nicaragua

Ottoman Empire

Russia

Greece-Serbia-Bulgaria-Italy

Greece-Bulgaria-Italy

Great Powers

Poland

Turkey

Kuomintang (Nationalists)

Bolivia

Italy

China-USSR

USSR

Allies

Vietnam
Paraguay 1

Spain 1

Austria

France

Egypt

Serbia

Ottoman Empire

Afghanistan 0

Bolivia-Peru

Great Britain

China

Guatemala

Afghanistan 1

Serbia

Ethiopia

China

Italy

Greece

Spain

South African Republic

China

Russia 1

Honduras

Italy

Ottoman Empire

Ottoman Empire-Serbia 1

Central Powers

Soviet Union

1

Northern Warlords

Paraguay 1

Ethiopia 1

Japan 1

Finland 1

Axis

France 
Indo-Pakistani War of 1947-48

Arab-Israeli War of 1948-49

Algerian War of 1954-62

Arab-Israeli War of 1956

Vietnam War (1956-75)

Sino-Indian Border Dispute (1959-62)
India

Israel

Algeria

Israel

Democratic Republic of Vietnam

China
Pakistan

Arab Nations

France

Egypt et al.

U.S.

India 